\title{
Distribution of HCV genotypes among different exposure categories in Brazil
}

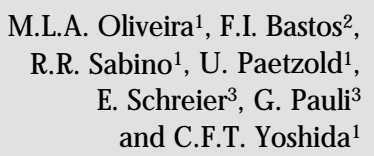

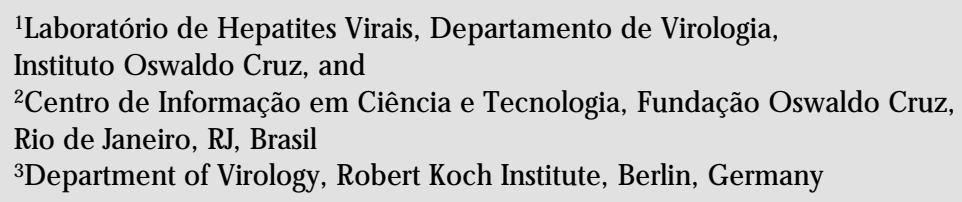

\section{Correspondence \\ M.L.A. Oliveira \\ Laboratório de Hepatites Virais \\ Departamento de Virologia \\ Instituto O swaldo Cruz, FIOCRUZ \\ Av. Brasil, 4365 \\ 21040-360 Rio de Janeiro, RJ \\ Brasil \\ Fax: + 55-21-270-6397 \\ E-mail: lou@gene.dbbm.fiocruz.br \\ M.L.A. O liveira is the recipient of a fellowship from the Robert Koch Institute, Berlin, Germany. F.I. Bastos and C.F.T. Yoshida are recipients of fellowships from $\mathrm{CNPq}$.}

Received May 12, 1998 Accepted November 10, 1998

\section{Abstract}

Hepatitis $\mathrm{C}$ virus (HCV) infection is widespread and responsible for more than $60 \%$ of chronic hepatitis cases. HCV presents a genetic variability which has led to viral classification into at least 6 genotypes and a series of subtypes. These variants present characteristic geographical distribution, but their association with different responses to treatment with interferon and severity of disease still remains controversial. The aim of this study was to investigate the patterns of distribution of HCV genotypes among different exposure categories in Brazil. Two hundred and fifty anti-HCV positive samples were submitted to HCV-RNA detection by RT-PCR and their genotype was determined by restriction fragment length polymorphism (RFLP) analysis. In addition, the genotype/subtype of 60 samples was also determined by a reverse hybridization assay. HCV 1 was the most prevalent $(72.0 \%)$, followed by type $3(25.3 \%)$, HCV $2(2.0 \%)$ and HCV $4(0.7 \%)$. The HCV genotype distribution varied among the different exposure categories, with HCV 1 being more frequent among blood donors, hemophiliacs and hemodialysis patients. A high frequency of HCV 3 was observed in cirrhotic patients, blood donors from the South of Brazil and injecting drug users (IDUs). The general distribution of the HCV genotype in Brazil is similar to that in other regions of the world.

Hepatitis $\mathrm{C}$ virus (HCV) was identified by Choo et al. (1) and there is a growing consensus to classify it into the family Flaviviridae (2). Hepatitis $\mathrm{C}$ constitutes a public health issue of major importance since more than $90 \%$ of patients develop chronic liver disease and this viral infection is considered to be the major risk factor for hepatocellular carcinoma in the world $(3,4)$.

The HCV genome consists of a positive stranded RNA of approximately $9.5 \mathrm{~kb}$. The genetic heterogeneity of HCV led to its classification into phylogenetic clusters. The
Key words

- HCV

- HCV genotypes

- Brazil widest variation is observed among $\mathrm{HCV}$ isolates of distinct genotypes, which present $>25 \%$ of nucleotide divergence within the entire genome or subgenomic parts. These genotypes are further divided into subtypes, which present about $75-86 \%$ nucleotide homology. The narrowest divergence is found between viruses from a single strain, which constitute a quasispecies. Although there is no standardized classification system for $\mathrm{HCV}$ genetic variants, most investigators agree that there are at least 6 major genotypes and a series of subtypes $(2,5)$. 
Epidemiological data suggest that the distribution of HCV genotypes varies among different regions $(3,5,6)$. In addition, an association between the genetic variants and routes of transmission has been reported $(7,8)$. Although some authors found a correlation of HCV genotypes with clinical response to interferon therapy (9) as well as with the outcome of the disease (10), these aspects still remain controversial $(11,12)$.

Little is known about the molecular epidemiology of HCV in Brazil. The aim of the present study was to investigate the distribution of HCV genotypes among Brazilian subjects according to their exposure categories.

Sera and epidemiological data were kindly supplied by different public health laboratories, public blood banks and other medical institutions from different Brazilian states, from 1994 to 1996. A total of 250 anti-HCVpositive samples were investigated for the presence of HCV-RNA by RT-PCR.

Among the 78 blood donors tested, 8 samples were from the State of Acre (AC), 14 from Amazonas (AM), 9 from Rio Grande do Sul (RS), 24 from Pará (PA) and 23 from Rio de Janeiro (RJ). In addition, we tested 13 samples from cirrhotic patients from the State of Espírito Santo (ES), 30 samples from hemophiliacs and 56 from injecting drug users (IDUs) from Rio de Janeiro. We also tested 73 samples from hemodialysis patients from different states: 22 from Ceará (CE), 18 from São Paulo (SP), 14 from Minas Gerais (MG) and 19 from Mato Grosso (MT).

Viral RNA was extracted from $200 \mu 1$ of plasma, using the QIAmp Blood kit and QIAmp Tissue kit (QIAGEN GmbH, Hilden, Germany). The extracted RNA was eluted in $100 \mu 1$ of DEPC-treated water. Reverse transcription (RT) was carried out with $2.5 \mu \mathrm{l}$ of RNA in a final volume of $10 \mu \mathrm{l}$. The mixture was submitted to one cycle of $42^{\circ} \mathrm{C} / 60 \mathrm{~min}$ and another of $95^{\circ} \mathrm{C} / 5 \mathrm{~min}$. In the first and second PCR rounds we targeted sequences within the HCV 5 ' non-coding region (HCV 5'NCR) and we used $2.5 \mu 1$ of RT and first
PCR product, respectively, in a final volume of $25 \mu \mathrm{l}$. The cycling protocol included 35 cycles of $94^{\circ} \mathrm{C} / 1 \mathrm{~min}, 54^{\circ} \mathrm{C} / 1 \mathrm{~min}$ and $72^{\circ} \mathrm{C} /$ $2 \mathrm{~min}$, followed by a final cycle of $72^{\circ} \mathrm{C} / 5$ min. The sequences and genomic positions for the outer primers used were $1 \mathrm{~b}\left(5^{\prime}\right.$ GGTG CACGGTCTACGAGACC3'; 251-231) and 2a (5'GGCGACACTCCRCGAT3'; 5-21) and the inner primers were 56 (5'CGCAAGCA CCCTATCAGGGCAGT3'; 35-21) and 4 (5'GAGGAACTACTGTCTTCACGCAGAA3'; 218-195). The 260-bp PCR product was submitted to electrophoresis using a $2 \%$ agarose gel in TBE buffer and visualized by ethidium bromide staining under ultraviolet light.

$\mathrm{HCV}$ genotyping by restriction fragment length polymorphism analysis (RFLP) was performed as described elsewhere (8) and genotypes were determined according to Simmonds' classification (13). Since RFLP did not permit the determination of $\mathrm{HCV}$ subtypes, 60 samples previously genotyped by RFLP were also submitted to reverse hybridization (RH) using the INNOLIPA HCV II test kit (Innogenetics, Zwijndrecht, Belgium).

Univariate analyses, comparing $\mathrm{HCV}$ genotypes distribution between different exposure categories, were carried out using Epiinfo version 5.0 (Centers for Disease Control and Prevention, Atlanta, GA, USA, 1990). The chi-square or 2-tailed Fisher exact test was employed and results were considered to be statistically significant when $\mathrm{P}<0.05$.

One hundred and sixty (64\%) of the 250 anti-HCV-positive samples were also positive for HCV RNA. Table 1 shows that the predictive value of PCR was higher among persons at risk such as hemophiliacs $(100 \%)$, IDUs (76.8\%), and cirrhotic patients (76.7\%). The low frequency of HCV-RNA found among blood donors from the northern states may have been a consequence of sample damage due to unsuitable conditions of transportation and/or storage. HCV genotype was determined by RFLP in 150 samples. The most 
Table 1 - Distribution of HCV genotypes among different exposure categories.

AC, Acre; AM, Amazonas; PA, Pará; RJ , Rio de J aneiro; RS, Rio Grande do Sul; ES, Espírito Santo; CE, Ceará; MT, Mato Grosso; MG, Minas Gerais; SP, São Paulo. *P<0.04 (compared with blood donors and hemophiliacs from Rio de $\mathrm{J}$ aneiro ( $\chi^{2}$ or Fisher exact test).

\begin{tabular}{|c|c|c|c|c|c|c|c|}
\hline \multirow[t]{2}{*}{ Exposure category } & \multirow{2}{*}{$\begin{array}{c}\mathrm{N} \\
\text { tested }\end{array}$} & \multirow{2}{*}{$\begin{array}{c}\% \mathrm{PCR} \\
\text { positive }\end{array}$} & \multicolumn{4}{|c|}{ HCV genotypes } & \multirow{2}{*}{ Tota } \\
\hline & & & $1(\mathrm{~N}, \%)$ & $2(\mathrm{~N}, \%)$ & $3(N, \%)$ & $4(N, \%)$ & \\
\hline Blood donors & 78 & 50.0 & $27(79.4)$ & - & $7(20.6)$ & - & 34 \\
\hline $\mathrm{AC}$ & 8 & 25.0 & $2(100.0)$ & - & - & - & 2 \\
\hline AM & 14 & 7.1 & $1(100.0)$ & - & - & - & 1 \\
\hline PA & 24 & 41.6 & $9(90.0)$ & - & $1(10.0)$ & - & 10 \\
\hline RJ & 23 & 78.2 & $13(92.8)$ & - & $1(7.2)$ & - & 14 \\
\hline RS & 9 & 88.8 & $2(28.5)$ & - & $5(71.5)$ & - & 7 \\
\hline Cirrhotic patients (ES) & 13 & 76.9 & $6(60.0)$ & - & $4(40.0)$ & - & 10 \\
\hline Hemophiliacs (RJ ) & 30 & 100.0 & $24(80.0)$ & - & 5 (16.6) & $1(3.4)$ & 30 \\
\hline Injectable drug users (RJ ) & 56 & 76.8 & $22(56.4)$ & $3(7.7)$ & $14(35.9)^{*}$ & - & 39 \\
\hline Patients under hemodialysis & 73 & 52.0 & $29(78.4)$ & - & $8(21.6)$ & - & 37 \\
\hline CE & 22 & 45.4 & $5(50.0)$ & - & $5(50.0)$ & - & 10 \\
\hline $\mathrm{MT}$ & 19 & 52.6 & $10(100.0)$ & - & - & - & 10 \\
\hline MG & 14 & 57.1 & $8(100.0)$ & - & - & - & 8 \\
\hline SP & 18 & 55.5 & $6(66.6)$ & - & $3(33.4)$ & - & 9 \\
\hline Total & 250 & 64.0 & $108(72.0)$ & $3(2.0)$ & $38(25.3)$ & $1(0.7)$ & 150 \\
\hline
\end{tabular}

prevalent genotype was HCV $1(109 / 150$, $72.7 \%)$, followed by HCV 3 (38/150, 25.3\%) and HCV $2(3 / 150,2.0 \%)$.

In the 60 samples tested by $\mathrm{RH}$, the most frequent subtype was $1 \mathrm{~b}(35.0 \%)$, followed by $1 \mathrm{a}(30.0 \%), 3 \mathrm{a}(24.9 \%), 1 \mathrm{a}$ and $1 \mathrm{~b}(5.0 \%)$ and subtypes 1 and $4 \mathrm{c} 4 \mathrm{~d}$ (1.7\% each).

Except for one sample in which HCV 1 was identified by RFLP and HCV 4c4d was identified by RH, the two methods showed 98.3\% agreement.

The distribution of $\mathrm{HCV}$ genotypes among the different exposure categories is presented in Table 1. Among blood donors, $79.4 \%(27 / 34)$ had HCV 1 and 20.6\% (7/34) had HCV 3 . Among subjects from the northern region of Brazil (AC, PA and AM) and Rio de Janeiro (southeast), we found a predominance of HCV 1 infection (92.3 and $92.8 \%$, respectively). However, a different profile was observed in blood donors from RS (south), among whom genotype 3 was the most prevalent (71.5\%).

HCV 1 was detected in 78.4\% (29/37) of samples from hemodialysis patients whereas
HCV 3 was detected in $21.6 \%$ (8/37). Interestingly, individuals from the State of Ceará showed a higher frequency of HCV $3(50.0 \%)$ than subjects from other states. A high frequency of HCV $1(80.0 \%)$ was found among hemophiliacs, the group in which the only HCV 4 case was found in this study. Among cirrhotic patients, the majority of subjects were infected with genotype 1a, followed by genotype 3.

Although the most prevalent HCV genotype among IDUs was HCV 1 (56.4\%), a relatively high proportion of HCV 3 was noted in this population if compared with other exposure categories in Rio de Janeiro $(\mathrm{P}=0.04)$. Among blood donors, HCV 1 was the most frequent genotype. Interestingly, a higher frequency of genotype 3 was observed in the south. These results partially conflict with previous findings (14) where HCV 1 was the most frequent, although the authors also reported a high prevalence of HCV type 3 in that region.

Among hemodialysis patients, a significantly higher prevalence of genotype 3 was 
observed in subjects from Ceará and studies with larger number of samples should be carried out to confirm these findings.

Among hemophiliacs, genotype 1 was the most frequent. This has also been observed in Argentina (15) and the United States (5). The distribution of HCV genotypes among IDUs was similar to that observed in Berlin, Germany (16).

The agreement between the RFLP and INNOLIPA II results was $98.3 \%$. RFLP is faster and easier to perform compared with other techniques, and suitable for molecular epidemiological studies of large number of samples.

The general distribution of HCV genotypes in different exposure categories in Brazil was similar to that for Europe, with a higher frequency of genotypes 1 and 3, followed by type 2 and sparse cases of type 4 (5). Future more extensive surveys should be conducted to assess geographic differences in distribution of HCV genotypes in Brazil.

\section{Acknowledgments}

We thank all institutions which kindly supplied the serum samples.

\section{References}

1. Choo QL, Kuo G, Weiner AJ , Overby LR, Bradley DW \& Houghton M (1989). Isolation of a cDNA clone derived from a bloodborne non-A, non-B hepatitis genome. Science, 244: 359-362.

2. Okamoto H, Miyakawa $Y \&$ Mayumi M (1997). Molecular virology of hepatitis C virus. Viral Hepatitis Reviews, 3: 51-62.

3. Gish RG \& Lau J YN (1997). Hepatitis C: eight years old. Viral Hepatitis Reviews, 3: 17-37.

4. Di-Bisceglie AM (1997). Hepatitis C and hepatocellular carcinoma. Hepatology, 26 (Suppl 1): 34S-38S.

5. Schreier E, Roggendorf M, Driesel G, Hoehne M \& Viazov S (1996). Genotypes of hepatitis $C$ virus isolates from different parts of the world. Archives of Virology, 11 (Suppl): 185-193.

6. Davidson F, Simmonds P, Ferguson J C, J anvis LM, Dow BC, Follett EAC, Seed CRG, Krusius T, Lin C, Megyesi CA, Kiyokawa H, Olim G, Dusaisamy G, Cuypers T, Saeed AA, Teo D, Conradie J, Kew MC, Lin M, Muchaprayoon C, Ndimble OK \& Yap PL (1994). Survey of major genotypes and subtypes of hepatitis $C$ virus using RFLP of sequences amplified from the $5^{\prime}$ non-coding region. J ournal of General Virology, 75: 23932398.

7. PawlotskyJ M, Tsakiris L, Roudot-Thoraval F, Pellet C, Stuyver L, Duval J \& Dhumeaux D (1995). Relationship be- tween hepatitis C virus genotypes and sources of infection with chronic hepatitis C. J ournal of Infectious Diseases, 171: 1607-1610.

8. Driesel G, Wirth $D$, Stark $K$, Baumgarten R, Sucker U \& Schreier E (1994). Hepatitis $\mathrm{C}$ virus (HCV) genotype distribution in German isolates: studies on the sequence variability in the E2 and NS5 region. Archives of Virology, 139: 379-388.

9. Bell $\mathrm{H}$, Hellum $\mathrm{K}$, Harthug $\mathrm{S}$, Maeland $\mathrm{A}$, Ritland S, Myrvang B, von-der-Lippe B, Raknerud N, Skauj K, Gutigatrd BG, Skjaerven R, Prescott RE, Simmonds P \& Construct group (1997). Genotype, viral load and age as independent predictors of treatment outcome of interferon-alpha 2a treatment in patients with chronic hepatitis C. Scandinavian J ournal of Infectious Diseases, 29: 17-22.

10. Garcia-Samaniego J , Soriano V, Castilla J , Bravo R, Moreno A, Carbo J, Iniguez A, Gonzalez J \& Munoz F (1997). Influence of hepatitis $C$ virus genotypes and HIV infection on histological severity of chronic hepatitis C. The Hepatitis/HIV Spanish Study Group. American J ournal of Gastroenterology, 92: 1130-1134.

11. Kobayashi $\mathrm{Y}$, Watanabe $\mathrm{S} \&$ Konishi $\mathrm{M}$ (1993). Quantitation and typing of serum hepatitis C virus RNA in patients with chronic hepatitis $\mathrm{C}$ treated with interferonbeta. Hepatology, 18: 1319-1325.

12. Margia A, Cascavilla I, Lezzi G, Spirito F,
Maertens G, Parlatone L, Saracco G, Rizzetto M \& Andriulli A (1997). HCV genotypes in patients with liver disease of different stages and severity. J oumal of Hepatology, 26: 1173-1178.

13. Simmonds $P$, Holmes EC, Cha TA, Chan SW, McOmish F, Invine B, Bell E, Yap PL, Kolberg J \& Urdea MS (1993). Classification of hepatitis $C$ virus into six major genotypes and a series of subtypes by phylogenetic analysis of NS-5 region. J ournal of General Virology, 74: 23912399.

14. Krug LP, Lunge VR, Ikuta N, Fonseca ASK, Cheinquer $\mathrm{H}$, Ozaki LS \& Barros SGS (1996). Hepatitis C virus genotypes in Southern Brazil. Brazilian J ournal of Medical and Biological Research, 29: 16291632.

15. Picchio GR, Nakatsumo M, Boggiano C, Sabbe R, Corti M, Daruich J , Perez-Bianco $\mathrm{R}$, Tezamos-Pinto M, Kokka R, Wilber J \& Moster D (1997). Hepatitis C virus (HCV) genotype and viral titer distribution among Argentinean hemophilic patients in the presence and absence of human immunodeficiency virus (HIV) co-infection. J ournal of Medical Virology, 52: 219-225.

16. Stark K, Schreier E, Mueller R, Wirth D \& Bienzle U (1995). Prevalence and determinants of anti-HCV seropositivity and HCV genotype among intravenous drug users in Berlin. Scandinavian J ournal of Infectious Diseases, 27: 331-337. 